\title{
PRIMARY PRESUMPTIONS FOR WEBSITE OPERATOR'S LIABIILTY FOR OFFENSIVE COMMENTS
}

\author{
Vaidas Jurkevičius ${ }^{1}$, Jūratė Šidlauskienè ${ }^{2}$ \\ ${ }^{1}$ Vilnius Gediminas Technical University, Sauletekio al. 11, 10223, Vilnius, Lithuania \\ ${ }^{1,2}$ Mykolas Romeris University, Ateities st. 20, 08303 Vilnius, Lithuania \\ E-mails: ${ }^{1}$ vaidas.jurkevicius@vgtu.lt (corresponding author); ${ }^{2}$ jurate.k@mruni.eu
}

\begin{abstract}
In 2013 and 2015 the European Court of Human Rights (ECHR) by its judgements in the famous case Delfi $A S v$. Estonia admitted the possibility of liability of the Internet news portal operator for unlawful comments of users. However, just half a year later, the ECHR in MTE \& Index v. Hungary case, which was, at first sight, similar, took a different decision, i.e. that the website operator could not be held liable. Finally, in 2017 the ECHR in Pihl v. Sweden case resolved a dispute over a comment posted in a blog. Thus, this article analyses, by applying the comparative method, the primary presumptions for website operator's liability established in the above mentioned cases. The authors define the criteria for assessment of the context of comments and models of conduct of website operators and set certain general waymarks, which could be applied in similar cases.
\end{abstract}

Keywords: Delfi AS v. Estonia, MTE \& Index v. Hungary, Pihl v. Sweden, website operator' liability, internet commentators' liability, liability for offensive comments.

JEL Classification: K12, K20.

\section{Introduction}

Though it would be customary and right to think that website commenters themselves should bear liability for offensive comments posted by them, however judgments of international courts show that in certain cases website operators themselves can be held liable for comments that were not deleted promptly. Such case law is called unexpected (Synodinou, 2015), controversial (McCarthy, 2015; Human Rights Violations Online, 2014), confused (Hall, 2017), able to radically change the business environment of information service providers (Cox, 2014) and posing threat for sustainability of the business of website operators as business entities (van der Sloot, 2016). It is namely business sustainability integration that has and will continue to have ever increasing influence on strategies and operations of business entities (Dyllick \& Muff, 2016). Therefore, it is very important to balance online rights of website operators and users, which have different interests, to the utmost extent possible.

On 10 October 2013, the First Section of the European Court of Human Rights (hereinafter referred to as the ECHR) unanimously, and on 16 June 2015, the Grand Chamber of the ECHR - by the majority of votes (15 votes in favour, 2 against) by their judgement in case Delfi $A S$ v. Es- tonia admitted the possibility of liability of the Internet news portal operator for unlawful comments of Internet users. Essential significance in admitting liability of Delfi $A S$ had its commercial status, professional management of the website, the nature of the comments, control over them and the duration of public accessibility of comments.

However, already in the judgement in case Magyar Tartalomszolgáltatók Egyesülete \& Index v. Hungary (hereinafter referred to as MTE \& Index v. Hungary) published on 2 February 2016, the ECHR slightly modified criteria for liability of Internet portal operators formulated in Delfi $A S v$. Estonia case, interpreting them more favourably for operators (Weinert, 2016). In this specific case, the ECHR stated impossibility of liability of the operator of the Internet news portal for its visitors' comments.

Though the judgement in Delfi AS v. Estonia case emphasizes that it is not related to Internet portals of different nature, social networks and websites or blogs operated by private persons, this judgement was directly referred to in the judgement passed by the ECHR on 7 February 2017 in the case Rolf Anders Daniel Pihl v. Sweden (hereinafter referred to as Pihl v. Sweden) in resolving a dispute over a comment posted in a blog. In this case, where impossibility of liability of the blog 
operator was stated, the nature of comments themselves, low awareness of the blog in the public and the non-commercial legal status of its operator, comments removal term and duration of their public accessibility had essential significance.

These judgements of the ECHR induce a wider analysis of the context of the comments and the conduct of the website operators in the process of removing them in order to establish whether the current case law of this court has formed a universal standard of assessment of the context of comments and proper actions of an Internet news portal, implementation of which would enable one to avoid negative consequences. Given the fact that the situation that emerged due to different regimes of establishing liability of Internet intermediaries (Gasser \& Schulz, 2015) is in general deemed not fully certain, defined, sometimes - even fragmented (van der Sloot, 2015), it is important to answer this question also when one wants to choose a business performance model, as similar Internet portals operate in each contemporary state and in many cases they face identical problems.

This article is the continuation of the authors' research on the topic of website operator's liability for offensive comments (Šidlauskienè \& Jurkevičius, 2017). The object of the article - the judgements of the ECHR in the cases Delfi $A S v$. Estonia, MTE \& Index v. Hungary and Pihl v. Sweden. The aim of this article is to investigate the criteria for assessment of the context of comments and models of conduct of website operators established in those cases and set certain general waymarks, which would apply to cases of this kind.

\section{Facts and essence of the disputes in the cases before the ECHR}

Before analysing the context of comments posted on the websites, as investigated in Delfi $A S$ v. Estonia, MTE \& Index v. Hungary and Pihl v. Sweden, the content of such comments and actions of website operators, it is important to assess particularities of these specific cases.

\subsection{Delfi AS vs. Estonia}

On 24 January 2006, one of the largest Estonian news portals - www.delfi.ee - posted a publication to the effect that after the shipping company $S L K$, which provides public ferry transport services, changed ferry routes, ferries damaged ice and, therefore, opening of cheaper ice roads con- necting the continental part of Estonia and its islands in winter had to be postponed for several weeks.

The article could be commented on by nonregistered users, anonymously, comments were not edited, and the commenting rules said that it was the author of comments that was liable for the content of his or her comments. The rules also said that Delfi $A S$ had the right to remove comments that were not in line with good practices and in general to restrict the commenting possibility for their authors.

The article received 185 comments of anonymous readers per day and the content of about 20 comments (i.e. 10.81 percent) contained pronouncements of threatening and offensive character in respect of L., who was a member of the Supervisory Board and the main shareholder of SLK. On 9 March 2006, L. through his advocate addressed Delfi $A S$, requesting to immediately remove unlawful comments and pay him a compensation of EUR 32,000 for non-pecuniary damages. On the same day, Delfi $A S$ removed the said comments.

On 25 June 2007, the Harju County Court rejected a statement of claim of L. for compensation for non-pecuniary damages. After the Tallinn Court of Appeal remitted the case for re-examination, on 27 June 2008 the court of first instance awarded from Delfi $A S$ non-pecuniary damages in the amount of EUR 320. On 16 December 2008, the Tallinn Court of Appeal upheld the judgement. On 10 June 2009, the Supreme Court of Estonia basically upheld the judgement, too.

On 4 December 2009, Delfi $A S$ addressed the ECHR, indicating that national courts violated the freedom of expression guaranteed by the European Convention on Human Rights.

\subsection{MTE \& Index v. Hungary}

On 5 February 2010, MTE - the Hungarian association for self-regulation of Internet content providers, which ensures compliance with the codes of professional activities and ethics of Internet content providers and controls the arbitration commission, decisions of which are binding on all eleven members of MTE, published its opinion on misleading practices in two real estate management websites owned by the same company, according to which users were provided with free of charge advertising services for 30 days, upon expiry of which they were charged for without any prior notice to the users. What is more, any outdated announcements and personal data used to be 
removed from the websites only after the user paid all overdue charges imposed without his knowledge. Such conduct of the company was possible because users, when registering on the website, had to accept the rules, which the service provider could amend unilaterally.

Articles posted on MTE website could be commented by registered users, but the content of the comments was not edited. The website also said that unlawful comments were not allowed to be posted, but they were removed only upon a separate request of any reader. Besides, it was indicated that it was the authors who were liable for the content of their comments.

At about that time, a private limited liability company Index, the owner of one of the largest Internet news portals in Hungary, discussed the opinion of MTE in an article published in the consumer protection column and published the whole text of the opinion. Articles on Index website could be commented by registered users, who were the ones held liable for the content of their comments, and the content was edited only to some extent. The website also said that comments infringing upon third party rights were not allowed in the portal, but they used to be removed either upon receipt of a separate request of any reader or, in case of necessity, a comment could be removed on the initiative of Index. One of Index users, carrying a pseudonym, posted an unethical comment under this publication.

On 17 February 2010, the company managing real estate websites that were criticised online brought an action in court, by which is requested liability of MTE, Index and Zöld Újság Zrt because the opinion content was misleading and subsequent offensive comments infringed upon the company's right to good reputation. Having learnt about the forthcoming litigation, the respondents immediately and on their own initiative deleted the challenged comments. On 31 March 2011, the court sustained the claim in part and on 27 October 2011 the Budapest Region Court of Appeal basically upheld the judgement. On 13 June 2012, the Supreme Court of Hungary awarded about EUR 243 from MTE and Index for examination of the appeal.

On 27 May 2014, the Constitutional Court of Hungary stated that if the author of inappropriate comments was not known, establishing liability of website operators for readers' comments was constitutionally justifiable.

On 28 March 2013, MTE and Index addressed the ECHR regarding possible violation of
Article 10 of the European Convention on Human Rights.

\subsection{Pihl v. Sweden}

On 29 September 2011, an entry about participation of the applicant Pihl in activities of a Nazi party was posted in a blog of a small non-profit association. The blog allowed comments, but it was clearly indicated that comments were not checked before their announcement and that their content was responsibility of their authors. Commenters were also requested to follow standards of proper conduct and laws. Next day after the entry was posted, a defamatory comment of an anonymous commenter was posted.

On 8 October 2011, Pihl commented responding that the information in the blog was wrong and had to be immediately removed. On the following day both the blog entry and the comment were deleted. The association also posted a new entry in the blog about the erroneousness of the previous entry and apologized for it. However, the previous blog entry and the comment were still accessible online through search systems.

On 11 November 2011, the court of first instance rejected the claim of Pihl, by which he requested to award from the association that controlled the blog symbolic damages (1 Swedish krona, i.e. about 10 euro cents) caused by the defamatory entry and comment. Though later a superior court remitted the case for re-examination due to procedural violations, the claim was ultimately rejected. The court did not support the applicant's position that the association had to delete the comment as soon as it received an e-mail about posting of the comment. Pihl was claiming that the association was to be held liable as due to its actions the comment remained in the blog for 9 days and it was impossible to find the author of the comment as the IP address of the computer, from which the comment arrived, was registered in France.

On 11 March 2013, the district court rejected the applicant's appeal. On 28 November 2013, the appellate court upheld the judgement, and on 19 March 2014, the Supreme Court of Sweden refused to allow the applicant's appeal.

On 22 November 2014, Pihl addressed the ECHR regarding violation of Article 8 of the European Convention on Human Rights.

On 25 July 2015, the Chancellor of Justice (Justitiekanslern), referring to the 2013 judgment in Delfi AS v. Estonia case that was referred to the Grand Chamber, stated that the state did not vio- 
late the positive duty under Article 8 of the European Convention on Human Rights to ensure liability of the association to the applicant for defamatory comments as Member States were not absolutely obliged to pass legal acts in each separate case, enabling to impose liability on the blog operator for comments posted in the blog. On the contrary, in each specific case the balance of the right to privacy established in the European Convention on Human Rights and the freedom of expression guaranteed by the European Convention on Human Rights must be ensured.

\subsection{Similarities and differences of the cases before the ECHR}

In summary, similarity of the following facts in $M T E \&$ Index v. Hungary and Delfi AS v. Estonia cases can be stated:

1. The websites www.delfi.ee and www.index.hu are among the major news portals in their respective countries, run on a commercial basis.

2. www.mte.hu and the blog, where the entry was posted, as considered in Pihl v. Sweden case, are non-commercial websites operated by non-profit legal entities.

3. All the articles on the websites were published on topics sensitive for the public.

4. The style of the articles that were commented on was proper.

5. Readers of all the Internet portals had a possibility to comment on articles in them.

6. All the websites indicated that it was the authors of comments that were responsible for the content of their comments.

7. None of the websites edited the comments section, comments used to be deleted only according to notice-and-take-down principle.

8. All the challenged comments were written in a biting style.

9. At the time of litigation in courts, comments were already deleted.

Essential differences in facts of the above cases are as follows:

1. Legal status of the website operator and related economic interest. www.delfi.ee and www.index.hu are run on a commercial basis, whereas www.mte.hu and the blog, analysed in Pihl v. Sweden case, are non-commercial websites.

2. Content of the announced publication. In Pihl v. Sweden case, the blog entry was based on wrong information, thus its content was incorrect. Information in the websites discussed in Delfi AS v. Estonia and MTE \& Index v. Hungary cases was objective and true.

3. Non-identity of the injured parties. The publication posted on www.delfi.ee was related to commercial activities of a company (SLK) and unlawful comments were made about its main shareholder and a member of the Supervisory Board - a natural person, who later defended namely his personal moral rights. In the Hungarian and the Swedish portals, both the article and the comments were about the same person.

4. Non-identity of persons who filed complaints with the ECHR. In Delfi AS v. Estonia and MTE \& Index v. Hungary cases, the ECHR was addressed by the operators of the websites containing a comments section, complaining about violations of Article 10 of the European Convention on Human Rights. Meanwhile, in Pihl v. Sweden case, the complaint was filed by a private natural person, claiming that the state, failing to hold the blog operator liable for the defamatory blog entry and the anonymous comment, violated the right to privacy and reputation guaranteed to him by Article 8 of the European Convention on Human Rights.

5. The different character of the infringed interest arising out of the aspects mentioned above: $S L K$ shareholder, as well as the Swedish resident Pihl, defended their reputation as that of a natural person moral right to honour and dignity, whereas in MTE and Index case a legal entity defended its commercial (business) reputation, which is not identical to the first one in terms of morals and values (Uj v. Hungary, 2011).

6. Commenting possibilities. The website www.delfi.ee and the Swedish blog allowed commenting anonymously, without registration, whereas the Hungarian portals permitted only registered users to have a say.

7. Partly different system of removal of unlawful comments. All the websites used to remove comments only according to the notice-and-take-down principle and only in www.index.hu the content of the com- 
ments was somewhat edited and a comment could be deleted on the initiative of Index itself. Besides, the operator of the Swedish blog used to receive an e-mail about a posted comment and www.delfi.ee website had a word screening system, which automatically blocked comments with roots of vulgar words.

8. Use of pre-trial dispute resolution procedure. In Delfi AS v. Estonia case, the injured party made a request to remove unlawful comments and they were deleted by Delfi $A S$ already on the date of the request. In Pihl v. Sweden case, the injured party Pihl, 9 days after posting of the blog entry, made a comment beneath it about incorrectness of the information and already next day not only the comment but also the blog entry were removed. In MTE \& Index $v$. Hungary case, the injured company did not address the website operators at all and went straight to court.

\section{Criteria for liability of an Internet news portal for offensive comments of its visitors}

The Internet space, as a seamless and everywhere accessible virtual environment, is usually contrasted to national jurisdiction of individual states, that have certain exceptional legal regulation peculiarities. Paradoxically, though it is admitted that application of different liability standards to all participants of the same virtual environment would be basically unjustifiable, namely courts of separate states faced an especially difficult task, i.e. to balance rights and duties of website operators, as new generation Internet means, Internet users (commenters) and addressees of their comments (third parties), that are so important in the democratic society, on the generally acceptable scale.

In Delfi AS v. Estonia case, the ECHR modified criteria for liability for notifications in the press, as applicable to mass media, that were formed as far back as in 2008 in the famous Axel Springer $A G$ v. Germany and Von Hannover $v$. Germany (No. 2) cases, and, stating liability of Delfi $A S$, it formulated criteria for liability of an Internet portal for non-removal of unlawful comments made in it by third parties.

However, just half a year later, i.e. on 2 February 2016, the ECHR in MTE \& Index v. Hungary case, which was, at first sight, similar, took a different decision, i.e. that the website operator could not be held liable.
The fact that just in half a year the ECHR passed different judgments on a similar issue, both of which were subsequently referred to in Pihl $v$. Sweden case, certainly calls for an analysis how and to what extent the operator of a website with a comments section can (and must) ensure that the content of comments would not breach third party rights and individual states would no longer face analogous consequences. As it is obvious from the judgements in Delfi AS v. Estonia, MTE \& Index v. Hungary and Pihl v. Sweden cases that the final outcome of the case is materially affected by proper assessment of the context of the comments and the content of the comments, as well as preventive actions or actions ensuring prompt deletion of comments, which were taken by the website operators, below we analyse namely this criteria, also taking into account the significance of the $l e-$ gal status of a website operator.

\subsection{Context of the comments and the content of the challenged comments}

In Delfi AS vs. Estonia case, it was established beyond doubt that the article commented on about breaking of ice roads significant for a large part of the society was lawful, did not infringe on third party rights, however the ECHR noted that the operator of the professionally managed website run on a commercial basis has to foresee that even neutral topics can provoke heated discussions online. The ECHR particularly noted that profitseeking Delfi $A S$ in its own turn was interested in attracting as many comments on its articles as possible, as the number of visitors depended on this, and the bigger number of visitors meant more income from advertising. Thus, Delfi $A S$ directly integrated the comments section in its website in order that visitors would leave their opinions in their comments and invited them to comment, as it was economically useful for Delfi $A S$. Besides, authors of the comments did not have any technical possibilities to modify or delete such comments, therefore it was admitted that Delfi $A S$ was not in line with the concept of a provider of purely technical services, and solely the fact that the company was not the author of the comments did not mean that it could not control the comments section.

To sum up, the essential significance for the final outcome of the case, with regard to the context of the comments, lay in the fact that the comments platform was integrated on the initiative of Delfi $A S$ itself, it was economically interested in as many comments as possible and basically only Delfi $A S$ had technical possibilities to control the comments section. 
Namely the latter explanations by the ECHR caused most discussions about compatibility of the ECHR jurisprudence with the case law of the Court of Justice of the European Union (hereinafter referred to as the CJEU) in application of the E-commerce Directive (2000), according to which no general information monitoring duty is imposed on information society service providers and solely the fact that an Internet service provider gets paid for placement of certain Internet content or links does not per se prevent it from relying on defence measures established in the E-commerce Directive. Meanwhile, in Delfi AS v. Estonia case the website operator was held liable because it did not, on its own initiative, monitor and remove third parties' comments, in making of which it was economically interested. In other words, according to the case law of the ECHR, a permission for Internet users to make comments, content of which is controlled by the news portal itself, is to be admitted to be an activity in the field assigned to mass media, which falls outside the scope of the E-commerce Directive. L. Brunner criticizes such a position, stating that a website operator controls only content created by itself but not that generated by users, therefore, in respect of the latter, Delfi $A S$ is to be treated as an intermediary for the purposes of the E-commerce Directive, which is subject to the principles formulated in the CJEU cases (Brunner, 2016). Thus, in the opinion of L. Brunner, Delfi $A S$, in terms of Internet content created, published and edited by it, should be regarded as a mass medium, which is not subject to the E-commerce Directive, whereas in terms of content created by Internet users, Delfi $A S$ should be admitted to be an intermediary providing an online platform. Therefore, especially unless it is determined that Delfi $A S$ somehow encouraged writing or reading comments, that it took additional measures in order to increase accessibility of comments and that Delfi $A S$ representatives knew of the unlawful nature of the comments before they received the request to delete the comments, Delfi $A S$ should have been recognised as an intermediary for the purposes of the E-commerce Directive and the rules formed in Google France cases (C-236/08, C-237/08, C-238/08), L'Oréal SA v. eBay case (C-324/09) and Scarlet Extended (C-70/10) case. S. Stalla-Bourdillon also states that ex ante or ex post moderation systems of which the aim is to eliminate the transmission of unlawful content, should not per se make an internet service provider a speaker (StallaBourdillon, 2017). According to Ch. Angelopoulos, the divergence between the ECHR ruling in
Delfi AS case and EU law as enshrined in the ECommerce Directive and interpreted by the CJEU, in particular in L'Oréal SA and Scarlet Extended, cases, marks a conflict between Europe's two highest courts (Angelopoulos, 2016). In MTE \& Index v. Hungary case, the ECHR firstly noted that the comments left on the Hungarian websites, contrary than in Delfi AS v. Estonia case, did not express hatred and did not incite violence, therefore they were not clearly unlawful. In this way, it was admitted that a website operator can be held liable for non-removal of not of just any but only of clearly unlawful comments. Second, MTE is a non-profit association for self-regulation of Internet content providers, which is not economically interested in the number of comments. Still, the ECHR admitted the necessity to refer in this case to the criteria for liability of an Internet news portal, which were formulated in the judgement in Delfi $A S$ v. Estonia case, which failed to be referred to by the Hungarian courts.

The ECHR held that the article analysed in $M T E \&$ Index v. Hungary case discussed misleading business practice of two major real estate websites, which was detrimental to their customers, regarding which consumer protection authorities had already started investigation procedures. As public interest demanded ensuring a reasonable public discussion on many issues important for consumers and Internet users, comments beneath this article were treated by the ECHR as a contribution to public interest.

The ECHR particularly emphasized that In$d e x$ is the operator of a major website run on a commercial basis and obviously receiving a large number of comments (the same as Delfi AS), however MTE, on the contrary, is the association for self-regulation of Internet content providers, the website of which was dominated by information of professional character and it was hardly probable that it could provoke heated discussions online. The ECHR also admitted that use of vulgar phrases is not per se a decisive criterion in assessing the character of an offensive comment, as the protection of the freedom of expression does not apply to unreasonable, underserved humiliation, for example, if the only purpose of a comment is to insult, however style constitutes part of the communication as the form of expression and is as such protected together with the content of the expression.

It was established in Pihl $v$. Sweden case that the blog entry was posted by a small non-profit legal entity and the content of the article was wrong as it presented untrue data about a person's 
belonging to a Nazi party. The blog itself was not widely known in the public and the comment beneath that blog entry, though aggressive, did not incite violence or hatred. Besides, the blog operator, upon seeing the comment of the injured party under the entry, already on the next day removed not only the comment but also the entry itself, which in total were visible for nine days. What is more, the author of the entry made public apologies in the blog for dissemination of wrong information. It was also considered important that the comment was not related to political views of the applicant, as indicated in the blog entry, and in general was not anyhow related to its content, therefore the author of the entry could hardly foresee a possibility of such a comment. Besides, based on the arguments of the ECHR in the latter case, one can arrive at the conclusion that it is not required that at least small non-profit associations, which operate a website with a comments section, perform pre-monitoring of comments or install an efficient alert and deletion system. Thus, having evaluated the reasons presented by the ECHR in the judgement in Pihl v. Sweden case, if it is determined that a small non-profit legal entity published an entry with untrue information in an obscure Internet portal, which was followed by an aggressive comment, and soon after the notice about the faulty nature of the entry, removed both the entry and the comment, the operator of this blog was reasonably held not liable.

Such a tendency of development of the ECHR case law can seem a consistent continuation of the rules formed in Delfi $A S$ v. Estonia case, however, upon a more diligent analysis of the content of all the three judgements, it is evident that in later cases the ECHR introduces a certain gradation of unlawful comments and to a certain extent admits impossibility of the duty to monitor content of all comments, which was assigned to websites in Delfi AS v. Estonia case. What is more, the ECHR pays too little attention to similarity of facts of the cases and basically focuses on two differences in facts, which are the website legal status and the character of comments themselves, which, in addition to actions of the website operators, are the criteria determining the outcome of the case. Such a positions is to be criticised for several reasons.

First, though www.index.hu and www.delfi.ee are almost identical, professionally managed, commercial Internet news portals economically interested in the content and quantity of comments and having control over their content, the ECHR basically accentuated non-commercial status of MTE and its purpose - to encourage reasonable public discussions on issues relevant to many consumers and Internet users and absence of economic interest to urge users to write comments. Therefore, the meaning of the criterion of "a professionally managed, commercial website interested in attracting as many comments on articles published by it as possible, which are controlled only by the website itself", as formed in Delfi $A S$ v. Estonia case, is obviously different in these cases: the criterion was of essential significance in Delfi $A S$ v. Estonia case, admitting liability of Delfi $A S$, whereas in MTE \& Index v. Hungary case the opposite - non-commercial - legal status of MTE was accentuated. The same noncommercial status of the blog operator was also underlined in Pihl v. Sweden case, noting that imposition of liability for visitors' comments on non-profit entities can be particularly detrimental. Thus, it will be considerably more difficult for Contracting States to claim that a pressing social need in a democratic society existed to justify the imposition of liability on an online intermediary, managed on a non-profit basis, for anonymous and unlawful comments posted on its website, than on big and powerful news portal like Delfi AS (Spano, 2017).

Second, in MTE \& Index v. Hungary case the ECHR usually pronounced on liability Index and MTE in common, basically failing to evaluate either the status or the purpose or the actions of In$d e x$ and automatically applying the same identical protection as to MTE. The fact that the ECHR in its judgement did not separately analyse criteria for possible liability of Index is in conflict with the criticism for national courts as set out in the judgement of the ECHR itself in MTE \& Index v. Hungary case to the effect that they did not evaluate the different role of Index and MTE in creating and publishing comments. Thus, though Hungarian courts in general did not consider different interest of the companies in the number and content of comments, and the ECHR - on the contrary focused on the legal status of MTE different from that of Index and Delfi $A S$, in both the cases the outcome of the case was determined by identical arguments, which should not be the case (Šidlauskienè \& Jurkevičius, 2017). Still, with regard to the example of Delfi AS v. Estonia case, one may have reasonable doubts whether in case if the initial text had been published by Index itself instead of copying it from MTE, the ECHR judgement in this case would have been different or not. 
Third, assuming that the legal status of the initial source of publication, to be specific, the operator of the website run for non-commercial purposes in MTE \& Index v. Hungary and in Pihl $v$. Sweden cases, was assessed by the ECHR as important for arising of liability of an Internet news portal run on a commercial basis, a question should arise whether the legal form of an Internet website operator can in general be a significant criterion in deciding on liability of the website operator, as the damage and other inconveniences suffered by the injured party are determined by claims in the comments but not by the fact whether or not the operator of an Internet news portal seeks and/or gets economic benefit from comments. In the opinion of the authors of this article, as public legal entities also have the right to seek and earn profit, stating presence or absence of economic interest in the number and content of comments based solely on the legal form of a legal entity or different character of the website are not and cannot be decisive criteria when taking a decision on holding the website operator liable, as they are not oriented either to actions/omissions of a specific entity or to consequences resulting therefrom. What is more, legal regulation does not give a basis to apply different liability criteria to commercial and non-profit entities for identical conduct solely due to their different economic situation. Besides, after it turns out that a public legal entity faces a smaller risk of liability for nonremoval of unlawful comments of third parties, at the same time preserving a possibility to earn profit, this may induce choosing a model of business carried out through a public legal entity and/or may induce profit-seeking entities to rebut that they are not subject to liability because an article commented on was copied from a website operated by a public legal entity (Šidlauskienè \& Jurkevičius, 2017). Finally, website operators often carry out mixed functions and act both for commercial and non-commercial purposes (Caddell, 2016b), therefore it may be difficult to assign a website to a certain single category (Griffith, 2016). It means that the liability criterion based on the character of the website or the legal status of its operator in general cannot always be applicable. The authors note that consequences of unlawful comments do not directly depend either on the character of websites or on the legal form of their operators, so hardly would the rights of SLK shareholder L. have been infringed less if the comments about him had appeared not on www.delfi.ee but on another major website run on a commercial basis, but not offering any content
(Brunner, 2016) or, let's say, in L.'s Facebook or Twitter account (Caddell, 2016a).

Fourth, the analysed ECHR judgements do not clearly present the comments control standard applied to a website operator, which can determine liability for consequences caused to the injured parties by failure to remove unlawful comments. However, the case law of ECHR suggests that the degree of precision required to regulate a professional "publisher" may be lower than that needed to regulate intermediary, and lower still than that that required to regulate an individual or a private or domestic activity (Riordan, 2016). Thus, it is necessary to establish the evaluation criteria of the comments control standard for the classification of an internet service as an "intermediary" or a "publisher". What is more, the difficulty with this distinction is that to require the classification of an internet service simply replaces one vague test to another. Those categories are not always mutually exclusive, and it does not necessarily follow that a platform which publishes some material is not an intermediary in respect of other material (Riordan, 2016). Given the fact that contemporary Internet news portals usually have accounts in social networks, too, a question arises who should control comments on news/articles posted and/or shared therein by mass media representatives and whether, in case operators of Internet news portals do no remove unlawful comments made by readers from their social network profiles or do not take measures to remove them from other publicly accessible Internet users' accounts, these cases should also be subject to the judgements passed in Delfi AS v. Estonia, MTE \& Index v. Hungary and Pihl v. Sweden cases. The authors note that according to criteria formed in the ECHR case law when assessing the issue of liability of website operators of a different nature (than established in the analysed judgements, for example, Yahoo!, Facebook, Twitter, etc.), the issue of compatibility of case law formed by the ECHR and the CJEU in the area of application of the E-commerce Directive may arise.

Fifth, though the character of comments was admitted to be an essential difference among the cases, the judgements did not separately analyse the wordings of the comments admitted by national courts to be unlawful, rather the comments in each case were evaluated as a single complex of pronouncements. Therefore, it is difficult to understand from the ECHR judgements whether unlawfulness of each comment should be established in the case or whether the comments as a whole should be investigated, whether these 
ECHR judgements should be referred to as the universal standard for assessment of comments, which means that separate comments recorded in Delfi AS v. Estonia, MTE \& Index v. Hungary and Pihl v. Sweden cases in all events should be considered lawful or unlawful, respectively, or whether they should be considered such only after establishing identical factual circumstances, also it remains vague whether a decision on lawfulness of comments was, nevertheless, taken and should be taken ad hoc. Besides, though the ECHR analyses cases already settled by national courts according to tort law of respective countries, the analysed judgements failed to take into account that solely due to the variety in the systems of the European tort law, unlawfulness of the same comments in different countries can reasonably be assessed according to different criteria (for example, in some tort law systems unlawfulness is linked to properness of actions, whereas in some other systems - to the result of actions) (Digest of European Tort Law, 2018; Principles, definitions and model rules of European private law. Draft Common Frame of Reference (DCFR), 2009; Koziol, 1998), which may result in different assessment of similar comments.

Sixth, as liability is imposed on a website operator namely for consequences caused by the content of comments, it is obvious that in such cases the analysis of the content of comments should be one of the cornerstones of investigation in the case. However, both the ECHR judgements do not analyse the comments themselves in more detail and do not compare them and a judgement is based on abstract judgemental conditions, one of which - clear unlawfulness of comments - is even indicated an essential difference between comments in the first two cases. The criterion of clear unlawfulness of comments was already referred to in Pihl v. Sweden case, noting that the comment in the case was not clearly unlawful, as it did not incite violence and hatred, contrary than in Delfi $A S$ v. Estonia case. Still, we cannot see any analysis of the content of the comment in the judgement. Besides, MTE \& Index v. Hungary case presented a new criterion of normal online communication style that had not existed in the ECHR case law previously.

Seventh, arguments in both the analysed judgements enable to envisage also a certain gradation of unlawfulness of actions based on judgemental criteria, though specific components of this scale and their interrelationship remain vague. For example, in Delfi $A S$ v. Estonia and MTE \& Index v. Hungary cases the ECHR specified that comments that propagated hatred, violence or damage to physical integrity of individuals in a clear and open way were clearly unlawful, but it did not discuss in detail the content of the very concept of "clear and open" and did not distinguish any other possible cases of clear unlawfulness, did not discuss criteria for establishing such unlawfulness, nor did it reveal other levels on the scale of unlawfulness and the significance of conformity of comments to normal online communication practice in assessing the degree of (un)lawfulness of comments. It simply stated in Pihl $v$. Sweden case that, contrary than in Delfi $A S$ v. Estonia case, the comment that appeared on the blog did not incite violence and hatred, therefore, it was not clearly unlawful. Thus, basically it is not clear how one should properly distinguish a simply insulting or defamatory comment from a pronouncement that incites hatred and violence, which already would be treated as clearly unlawful (Angelopoulos \& Smet, 2016). Paradoxically, online intermediaries, in their discretion evaluating the unlawfulness of comments, are in some sense now acting as human rights arbiters (Jørgensen \& Pedersen, 2017).

On the other hand, thought the law interpretation and application rules formed in Delfi $A S v$. Estonia case that caused numerous discussions were not negated in the judgement in $M T E \&$ Index v. Hungary case, it clearly shows a tendency to adjust and modify them in a way more favourable for operators of Internet news portals - on the one hand, admitting a possibility of liability of website operators for damage caused to third parties by clearly unlawful comments of visitors, on the other hand, not imposing such liability for all comments, as a general rule. That is also reflected in Pihl v. Sweden case. Such a change in the ECHR case law is welcome as a positive turn aimed at maximal balancing of rights of participants in legal relationship with different interests, however it is only a transitional stage towards the ultimate goal.

The context of comments and their content are integrally related to the standard of conduct applicable to website operators, which is discussed below.

\subsection{Measures taken by website operator}

The ECHR noted that Delfi $A S$, seeking to prevent unlawful comments, took certain measures, therefore, it cannot be considered as having absolutely avoided its duty not to cause damage to third parties: www.delfi.ee announced that commenters 
were responsible for the content of their comments, indicated that posting comments contrary to good practices, threatening, offensive, obscene, vulgar comments, comments inciting hostility, discord, violence and illegal activities was prohibited, it also installed an automatic system of deleting comments containing roots of vulgar words and applied the notice-and-take-down principle, according to which any person could notify Delfi $A S$ about an improper comment simply clicking on a special button under a comment.

Though the Supreme Court of Estonia did not expressly state whether Delfi $A S$ had to prevent posting any unlawful comments or whether according to national law their immediate removal would have sufficed, the ECHR relied on the assumption that immediate removal of the comments would have been enough to avoid the liability. The ECHR indicated that if the notice-andtake-down system ensured efficient procedures of prompt response to improper comments, in many cases it could be considered a proper measure of balancing rights and interests of all the situation participants. In spite of the fact that the automatic word filtering system can be useful and sufficient, but in the specific case it was not sufficient and did not identify comments obviously inciting hatred and violence, which remained online for six weeks and were removed only upon receipt of the request from the injured party's advocate.

The ECHR also noted that possibilities of the injured party natural person to constantly monitor Internet content are more limited than the possibility for a large commercial Internet news portal to prevent or promptly remove such comments (McCarthy, 2015; Perry \& Zarsky, 2015). Consequently, it is not unproportioned restriction of freedom of speech (see previous decision of this topic in Krone Verlags GmbH \& Co. KG v. Austria (no. 4), 2006).

Thus, having evaluated that Delfi $A S$ had sufficient possibilities to control comments posted in its portal, the ECHR stated that imposing a duty on a company to remove clearly unlawful comments inciting hatred and violence immediately after their posting from its website would not be a disproportionate violation of the freedom of expression. The ECHR also took into account that while the case was pending Delfi AS had formed a special team of moderators to monitor comments.

In summary, it is to be noted that measures of protection against unlawful comments on the website www.delfi.ee operated by Delfi $A S$ were admitted by the ECHR to be insufficient as they did not detect comments with clearly unlawful content, which were removed only six weeks later, upon receipt of the injured party's request. Thus, according to argumentation of the ECHR in the judgement in Delfi $A S v$. Estonia case, in cases when clearly unlawful comments incite hatred, violence or infringe upon human rights provided for in the European Convention on Human Rights otherwise, the notice-and-take-down system is to be admitted sufficient only if it detects (and removes) such comments. It basically means imposing an absolute duty to monitor all posted comments (Frosio, 2017), totally ignoring actions of the website operator upon receipt of the injured party's request to remove comments and not applying the standard of actual awareness of unlawful comments (Caddell, 2016a). Authors agree with the position that the unprecedented rate and magnitude at which users generate and distribute content in the internet suggest that any liability scheme relying on intermediary monitoring, knowledge, or assessment of particular items of user-generated content is impractical. Such a scheme also would incentivize the suppression of protected speech (Omer, 2014).

Still, arguments of national courts in MTE \& Index $\mathrm{v}$. Hungary case that enabling posting of unedited comments, the company had to foresee a possible violation of third party rights, were admitted to be excessive, practically non-feasible requirements that can violate the right to share information online freely. Such application by Hungarian courts of objective liability, which basically cannot be avoided, to MTE and Index solely for the fact that, enabling readers to comment on articles, they assumed liability for any harmful or unlawful comments posted by visitors, was admitted by the ECHR to be unlawful. The ECHR also did not support the position of the Hungarian courts that the fact of removal of comments and measures of protection against unlawful comments applied by MTE and Index were legally insignificant circumstances, as MTE and Index took certain common measures to prevent possible unlawful comments or remove them immediately: comments could be posted only be registered visitors, both the applicants declared in the General Conditions of Commenting that it was not the website operator but the commenters who were responsible for the content of comments, provided for a prohibition to post comments infringing upon third party rights, installed an advance user registration system, both the applicants also used the notice-and-take-down system, according to which any person could notify the website operators of unlawful comments that should 
be deleted. Thus, the ECHR admitted the advance measures of protection against unlawful comments applied by MTE and Index to be sufficient and stated that they were held liable unreasonably.

The above shows that the ECHR in MTE \& Index v. Hungary case looked at the situation of companies operating Internet news portals from the perspective that was more in line with the CJEU case law and concretised the scope of the general duty formed in Delfi $A S v$. Estonia case to monitor all posted comments, actually stating that the unconditional duty to take immediate removal measures applies only in case of hate speech and inciting violence. However, hardly such a change in the position of the ECHR will alleviate the burden on Internet portals, as in order to assign comments to a certain category of unlawfulness, all of them have to be read all the same, and even top qualification lawyers do not always agree on qualification of comments. As the ECHR does not present any criteria for distinguishing between clearly and unclearly unlawful comments, it can hardly be expected that other persons without legal education monitoring comments will properly select and delete comments correctly.

In Pihl v. Sweden case, the court already referred to the classification of clearly and unclearly unlawful comments presented MTE \& Index $v$. Hungary case. The unethical comment posted under the blog entry of erroneous content was not recognised in this case as clearly unlawful, as it did not incite violence and hatred as "in Delfi $A S$ $v$. Estonia case". Such a conclusion was made in spite of the fact that the non-profit association received an e-mail about posting of a new comment on the blog entry and probably had more possibilities than Delfi $A S, M T E$ or Index to promptly remove this comment. The ECHR also assessed that the comment was not related to the entry content, therefore the blog operator could hardly foresee posting of such a comment.

The ECHR established in Pihl v. Sweden case that the blog permitted anonymous commenting, but it was clearly indicated that the comments were not checked before their announcement and it was the commenters who were responsible for their content. Commenters were also requested to comply with standards of proper conduct and laws. Pihl, about whom the erroneous blog entry was published, posted a comment under it indicating that the information in the blog was false and had to be removed immediately. Already on the next day, both the blog entry and the comment were deleted and the association posted a new entry in the blog about the erroneousness of the previous entry and apologised for it. The fact that the previous blog entry and the comment were still accessible online through search systems was not recognised as unlawfulness of the association's actions, as the person, about whom the comment was made, can address operators of such search systems for removal of this information (according to Google Spain case (C-131/12).

It is to be noted that Pihl v. Sweden case in general does not speak about pre-monitoring of the content of all comments or an installed automatic efficient system of comment filtering and deletion, it is also said that the content of the article did not allow to expect a comment of namely such content as posted. Therefore, it should be presumed that in cases about liability for unlawful comments that are not related to the content of the publication and which could not be foreseen, at least small non-profit associations are not required by the ECHR to take analogous measures as installed by Delfi $A S$ or even Index and MTE. The latter case examined by the ECHR also fails to answer the question whether such prompt removal of the comment along with public apologies can help website operators to avoid liability or whether in this case the apologies are relevant solely by reason that the initial publication was based on inaccurate information. In the authors' opinion, such public refutation of certain incorrect statements or publication of the injured party's pronouncement in certain cases truly could be a sufficient and considerably more proportionate method to ensure balance of rights of Internet intermediaries and their users to the freedom of expression and information and rights to privacy, however today it is difficult to say beyond doubt whether the ECHR would really support namely such a position. In any case, the argumentation in Pihl v. Sweden case is closer to the position of the ECHR in MTE \& Index v. Hungary case, which allows speaking of a possible embryo of certain consistent ECHR case law in this area.

Though the ECHR case law did not reveal the concept of "immediate" removal of comments and did not present any criteria for establishing such immediate removal, however promptness of removal of comments could be determined assessing the period, within which a comment could reach a large group of visitors, and taking into account legal consequences that the injured party actually suffered - the graver consequences are, the more probable that the removal was not prompt. Still, though judgements in MTE \& Index v. Hungary and Pihl v. Sweden cases sought to prevent 
possible cancellation of the comments sections, being afraid of the duty to indemnify for damages, the change in the ECHR position based on theoretical classification of comments did not practically narrow the requirements imposed on website operators by Delfi $A S$ v. Estonia judgement to monitor all comments and did not eliminate the threat of restricting possibilities of exercise of the freedom of lawful expression, as it will nevertheless be possible to assign comments to a certain classification category only by reading them all.

\section{Conclusions}

1. The context of posting comments online and measures taken by website operators in order to prevent unlawful comments are cornerstones in holding a website operator liable for unlawful comments posted by users on the website.

2. Assessing the context of comments, it is necessary to analyse the character of comments themselves, to assess control the website operator has over the comments section and the possibilities of the commenters themselves to edit their comments. According to the ECHR case law, the character of the legal status of the website operator also has significance for the final outcome of the case, but, in the authors' opinion, the legal form of the website operator or the type of the website should be treated only as additional criteria for establishing liability, as it is not them but namely the content of comments that causes negative consequences for the injured party. The character of the commented article is to be regarded as an additional element in assessment of the context of comments.

3. According to the ECHR case law, assessment of the comment context criterion implies a certain scale of unlawfulness of comments, where clearly unlawful comments at the top of such scale can make one subject to the strictest sanctions, meanwhile, if additional study is necessary in order to determine unlawfulness of comment content, it is evaluated according to the parameter of normal online communication practice. However, the ECHR case law did not reveal other possible cases of clear unlawfulness and did not distinguish criteria for determining them, did not indicate the remaining levels of the scale of unlawfulness and the significance of the conformity of comments to the normal online communication practice in assessing the level of (un)lawfulness of comments.
4. It is enough for website operators, who seek to avoid liability for damage caused by visitors' comments, to install an efficient system of screening and removal of already posted comments, but the procedure of their removal is different: a) clearly unlawful comments must be removed immediately after their posting on the website operator's initiative; b) it is enough to delete not so clearly unlawful comments right after receipt of a relevant request.

\section{Disclosure Statement}

Authors declare that they do not have any competing financial, professional, or personal interests from other parties

\section{References}

Angelopoulos, Ch. (2016). European intermediary liability in copyright: A tort-based analysis. University of Amsterdam.

Angelopoulos, Ch., \& Smet, S. (2016). Notice-and-fair-balance: How to reach a compromise between fundamental rights in European intermediary liability. Journal of Media Law, 8(2), 266-301.

https://doi.org/10.1080/17577632.2016.1240957

Axel Springer AG v. Germany. (2012). [GC] European Court of Human Rights, appeal no 39954/08.

Brunner, L. (2016). The liability of an online intermediary for third party content. The watchdog becomes the monitor: intermediary liability after Delfi v Estonia. Human Rights Law Review, 16(1), 163-174. https://doi.org/10.1093/hrlr/ngv048

Caddell, R. (2016a). The last post? Third party internet liability and the grand chamber of the European court of human rights: Delfi AS v Estonia revisited. Communications Law, 21(2).

Caddell, R. (2016b). Third party internet liability and the European court of human rights. Communications Law, 21(3).

Cox, N. (2014). Delfi AS v. Estonia: The liability of secondary internet publishers for violation of Reputational rights under the European Convention on human rights. Modern Law Review, 77(4). https://doi.org/10.1111/1468-2230.12081

Delfi AS v. Estonia. (2013). European Court of Human Rights, appeal no 64569/09.

Delfi AS v. Estonia. (2015). [GC]. European Court of Human Rights, appeal no 64569/09.

Digest of European Tort Law. (2018). In B. Winiger, E. Karner, \& K. Oliphant (Eds.), Essential Cases of Misconduct (Vol. 3). Berlin: Walter de Gruyter GmbH.

Directive of the European Parliament and of the Council on certain legal aspects of information society services, in particular electronic commerce, in the Internal Market (E-commerce Directive) (no 2000/31). Official Journal of the European Union, L 178, 17/07/2000, pp. 00010016 . 
Dyllick, T., \& Muff, K. (2016). Clarifying the meaning of sustainable business: Introducing a typology from business-as-usual to true business sustainability. Organization \& Environment, 29(2), 156-174. https://doi.org/10.1177/1086026615575176

Frosio, G. F. (2017). The death of 'No monitoring obligations': A story of untameable monsters. Journal of Intellectual Property, Information Technology and ECommerce Law, 8(3), 212.

Gasser, U., \& Schulz, W. (2015). Governance of online intermediaries observations from a series of national case studies. The Berkman Center for Internet \& Society Research Publication Series. Research Publication No. 2015-5. https://doi.org/10.2139/ssrn.2566364

Google France SARL and Google Inc. v. Louis Vuitton Malletier SA, Google France SARL v. Viaticum SA and Luteciel SARL and Google France SARL v Centre national de recherche en relations humaines (CNRRH) SARL and Others. (2010). Court of Justice of the European Union, joined cases no. C-236/08, C-237/08 C238/08.

Google Spain SL, Google Inc. v. Agencia Española de Protección de Datos (AEPD) and Mario Costeja González. (2014). Court of Justice of the European Union, case no. C-131/12.

Griffith, M. E. (2016). Downgraded to "Netflix and Chill": Freedom of expression and the chilling effect on usergenerated content in Europe. The Columbia Journal of European Law, 22(2), 355-38.

Hall, J. (2017). User-generated content on the internet, and intermediary liability for the dissemination of unlawful comments in the European Court of Human Rights. Nottingham Law Journal, 26(103).

Human rights violations online. European digital rights. Retrieved from https://edri.org/files/EDRI_CoE.pdf

Jørgensen, R. F., \& Pedersen, A. M. (2017). Online service providers as human rights arbiters. In M. Taddeo, \& L. Floridi (Eds.), Responsibilities of online service providers. Cham: Springer International Publishing. https://doi.org/10.1007/978-3-319-47852-4_10

Koziol, H. (1998). Unification of Tort Law: Wrongfulness. The Hague; London; Boston Mass: Kluwer Law International.

Krone Verlags GmbH \& Co. KG v. Austria (no. 4). (2006). European Court of Human Rights, appeal no 72331/01.

L'Oréal SA and Others v eBay International AG and Others [GC]. (2011). Court of Justice of the European Union, case no. C-324/09.

Magyar Tartalomszolgáltatók Egyesülete and Index.hu Zrt v. Hungary. (2016). European Court of Human Rights, appeal no 22947/13.

McCarthy, H. J. (2015). Is the writing on the wall for online service providers? Liability for hosting defamatory user-generated content under European and Irish Law. 14 Hibernian L. J. 16.
Omer, C. (2014). Intermediary liability for harmful speech: Lessons from abroad. Harvard Journal of Law \& Technology, 28(1).

Perry, R., \& Zarsky, T. Z. (2015). Who should be liable for online anonymous defamation?. The University of Chicago Law Review Dialogue, 82(162).

Principles, definitions and model rules of European private law. Draft Common Frame of Reference (DCFR). (2009). Study Group on a European Civil Code and the Research Group on EC Private Law (Acquis Group). Full Edition. C. Von Bar, \& E. Clive (Eds.). Munich: Sellier. European Law Publishers.

Riordan, J. (2016). The liability of internet intermediaries. New York: Oxford University Press.

Rolf Anders Daniel Pihl v. Sweden (Pihl v. Sweden). (2017). European Court of Human Rights, appeal no 74742/14.

Scarlet Extended SA v Société belge des auteurs, compositeurs et éditeurs SCRL (SABAM). (2011). Court of justice of the European Union, case no. C-70/10.

Šidlauskienè, J., \& Jurkevičius, V. (2017). Website operators' liability for offensive comments: A comparative analysis of Delfi as v. Estonia and MTE \& Index v. Hungary. Baltic Journal of Law \& Politics, 10(2).

Sotiris Papasavvas v O Fileleftheros Dimosia Etaireia Ltd, Takis Kounnafi, Giorgos Sertis. (2014). Court of justice of the European Union, case no. C-291/13.

Spano, R. (2017). Intermediary liability for online user comments under the European convention on human rights. Human Rights Law Review, 17(4). https://doi.org/10.1093/hrlr/ngx001

Stalla-Bourdillon, S. (2017). Internet intermediaries as responsible actors? Why it is time to rethink the E-commerce Directive as well. In Responsibilities of Online Service Providers. M. Taddeo, \& L. Floridi (Eds.). Cham: Springer International Publishing. https://doi.org/10.1007/978-3-319-47852-4_15

Synodinou, T.-E. (2015). Intermediaries' liability for online copyright infringement in the EU: Evolutions and confusions. Computer Law \& Security Review, 31. https://doi.org/10.1016/j.clsr.2014.11.010

Uj v. Hungary. (2011). European Court of Human Rights, appeal no 23954/10.

Van der Sloot, B. (2015). Welcome to the jungle: the liability of internet intermediaries for privacy violations in Europe. Journal of Intellectual Property, Information Technology and E-Commerce Law, 6(211).

Van der Sloot, B. (2016). The practical and theoretical problems with 'balancing'. Delfi, Coty and the Redundancy of the Human Rights Framework. Maastricht Journal of European and Comparative Law, 23(3), 439-459. https://doi.org/10.1177/1023263X1602300304

Von Hannover v. Germany. (2012). [GC] European Court of Human Rights, appeal no 40660/08 and 60641/08.

Weinert, E. (2016). MET v Hungary: the first European Court of Human Rights ruling on liability for user comments after Delfi AS v Estonia. Entertainment Law Review, 27(4). 